\title{
Diffusion of Innovation Assessment of Adoption of the Dry Port Concept
}

\author{
Violeta Roso ${ }^{a}$, Dawn Russell ${ }^{b}$, Dawna Rhoades ${ }^{c}$
}

Dry ports, when implemented effectively, reduce seaport congestion, improve seaport throughput and, due to the movement of containers from road to rail, reduce harmful emissions. This study investigates the implementation of dry ports at five U.S. seaports, which is then analysed considering the diffusion of innovation attributes. Data for the study was collected through face-to-face interviews at US East Coast seaports of Miami, Everglades, Jacksonville, Savannah and Charleston. To ensure validity, the triangulation of data sources was performed; i.e. a number of secondary sources were used, such as reports, internal and external documents, as well as site visits to the facilities. Three components have been recognized as key to the successful dry port concept: on/near-dock rail, reliable

\author{
KEY WORDS \\ $\sim$ Dry port \\ $\sim$ Seaport \\ $\sim$ Inland access \\ $\sim$ Diffusion of innovation \\ $\sim$ USA
}

a. Chalmers University of Technology, Division of Service Management and Logistics, Sweden

e-mail: violeta.roso@chalmers.se

b. Coggin College of Business, University of North Florida, Florida, USA

e-mail: dawn.russell@unf.edu

c. Management, Marketing, and Operations College of Business, Embry-Riddle Aeronautical University; Florida, USA

e-mail: rhoadesd@erau.edu

doi: 10.7225/toms.v08.n01.003

This work is licensed under (cc) BY inland rail connection and a functional inland intermodal facility. These three components have a diverse group of stakeholders, many of whom are unknown to one another; however, when coordinated, they create the innovation of the dry port concept. If the attributes of successful innovations are understood, with respect to their influence specifically on dry ports, then they can be managed to contribute to the successful implementation of dry ports. The novelty of the research lies in its approach of using the diffusion of innovation attributes that have been historically proven to impact the adoption rates of innovations to provide insight into the adoption of the dry port concept.

\section{INTRODUCTION}

The concept and the reality of dry ports have evolved in the past decade in response to growing global trade and the resultant increased demand for port logistics services. Dry ports have been established to reduce seaport congestion and improve throughput rates (e.g. Roso, 2007; Hanaoka and Regmi; 2011). When used in conjunction with on-dock rail, dry ports also reduce the negative effects on the environment because the containers are moved directly from road to rail, reducing harmful emissions from motor carrier vehicles (Roso, 2007; Henttu and Hilmola, 2011, Khaslavskaya and Roso, 2019).

One contributor to the growing demand for port logistics services in the U.S. is the Panama Canal expansion, which, in June 2016, began allowing vessels as large as 14,000 TEUs to traverse the canal and reach the East Coast of the U.S. directly, bypassing the heretofore heavily used land bridge option of entering the U.S. via LA/Long Beach ports and using rail to reach the densely populated markets of the U.S. East Coast. This creates significant opportunity and challenges for seaports on the U.S. East 
Coast, such as the seaports of Miami, Everglades, Jacksonville, Savannah, and Charleston. While larger vessels help carriers to reduce voyage cost, these savings are increasingly outweighed by higher port and landside costs (WCN, 2016a). Ports spend heavily on projects aiming to handle large vessels, with little guarantee of a return on their investments. There is fear that every region will likely see the number of ports reduced to just a few larger transshipment hubs, which will trigger "fantastic" competition between them. The challenge facing these ports is to increase their capacity and improve their inland access via dry ports to meet the new demand.

The term dry port in this study is used to refer to an inland intermodal terminal directly connected to seaport(s) by rail, where customers can leave/pick up their standardized units, as if directly at/from the seaport (Roso et al, 2009). Three components have been recognized as key to the successful dry port concept: (1) on-dock rail, (2) reliable inland connection and (3) a functional inland intermodal facility (Black et al, 2013, Roso et al 2009). These three components, taken together, make-up the innovation of the dry port concept (Roso et al, 2009). The concept has the potential to generate benefits for the ecological environment and the quality of life of residents by shifting freight routes from road to rail (Black et al, 2018; Roso et al, 2009). It mainly offers seaports the possibility to secure a market in the hinterland and increase the throughput without physical port expansion (Black et al, 2018). In this scenario, seaport cities and the seaports themselves benefit from less road congestion and a reduced need for infrastructure investment. Increasing seaport capacity without improving inland access leads to supply chain bottlenecks inland. With a growing demand for containerized freight transportation, efficiency of rail and flexibility of road are increasingly needed for inland access to and from the seaports.

The dry port concept involves an eclectic group of stakeholders, many of whom are unknown to one another. It is a challenge, when adopting the dry port concept, to create understanding and motivation across all stakeholders, regardless of their position in the inland access transport system. However, this challenge must be overcome to achieve the capacity growth and operational efficiency promised by dry ports that operate effectively in conjunction with their partner seaports.

Accordingly, the study investigates the influences on the adoption of dry ports through the lens of diffusion of innovation. The real innovation of the dry port are the three dry port components working together as a single innovation, i.e., (1) ondock rail, (2) reliable inland connection and (3) a functional inland intermodal facility working in a coordinated fashion as one innovation. If the influences on adoption can be understood, with respect to the three components working together, then the proven diffusion attributes can be managed to improve adoption rates, positively affecting port throughput, congestion and environmental impact.
The research questions in this study are:

- How does the diffusion of innovation attributes affect the adoption of dry ports?

- What are the challenges of diffusion of this dry port innovation?

In pursuit of these research questions, the remainder of this paper includes an explanation of the competitive importance of the dry port concept in Section 2. Section 3 discusses the port attributes of the five U.S. East Coast ports explored in this study: Miami, Everglades, Jacksonville, Savannah and Charleston. Section 4 of this paper explains the research approach and the diffusion of innovation, and presents the influence of diffusion attributes on our dry port concept of study. Section 5 presents our findings, including a theoretical diffusion model of dry ports, which details the specific impact of attributes on the three dry port components: (1) on-dock rail, (2) reliable rail connection and (3) a functional inland intermodal facility. Finally, Section 6 presents the conclusions, including contributions to research and managerial implications.

\section{COMPETITIVE IMPORTANCE OF THE DRY PORT CONCEPT}

Growth in ocean container freight traffic manifests itself in increased container port traffic volumes and demand for port services that require seaports to expand not only the capacity, but also the functionality of their services. However, due to the constrained supply of land available for seaport expansion, congestion, notably at major container ports, has intensified. With growing container transports, the efficiency of rail and the flexibility of road are increasingly needed for inland access to and from the ports. Competition requires ports to focus on their inland access (Roso et al, 2015; Rodrigue et al, 2010), on the demand for services in their traditional hinterland (Bask et al, 2014, Andersson and Roso, 2016), as well as on the development in areas outside their immediate market (Rodrigue et al, 2010). Many container ports around the world are implementing and developing dry ports, i.e. inland intermodal terminals directly connected to seaport(s) by rail, where customers can leave/pick up their standardized units, as if directly at/from the seaport (Roso et al, 2009). One of the aims of dry port implementation is to improve seaport inland access to increase competitive advantage, terminal capacity and consequently productivity. Such developments have been observed in China (Beresford et al., 2012), Australia and New Zealand (Roso, 2013; Black et al, 2018).), India (Ng and Gujar, 2009), the United States (Rodrigue et al, 2010, Roso et al., 2015), Asia (Hanaoka and Regmi, 2011; Black et al, 2013), Russia (Korovyakovsky and Panova, 2011), and Europe (Flämig and Hesse, 2011; Henttu and Hilmola, 2011; Monios, 2011, Bask et al, 2014, Khaslavskaya and Roso, 2019). To meet the increased demand on the East Coast due to the Panama 
Canal expansion, some of the seaports are extending their docks and acquiring new equipment to handle larger vessels. However, increasing capacity only at the seaport entry point, without improvements in inland connections, is insufficient for the proper functioning of the entire container transport chain. Hinterland connections beyond the seaport, where congested roads and inadequate connections cause delays and raise transportation costs, could well be the weakest link in the transportation chain of seaports experiencing this exponential increase in demand. To gain competitive advantage, seaports need to focus on their inland access, on the demand for services in their traditional hinterland, as well as on the development in areas outside their immediate market. One strategic approach to resolving economic and environmental issues is the expansion of intermodal (road and rail) transport through dry ports/inland ports.

Sustainable inland access is a key element in maintaining competitive seaport capacity and operational efficiency levels. Seaports have replaced their earlier narrow focus on cargo handling with a wide range of logistic activities, giving them a more active role of offering door-to-door rather than port-toport transport solutions (Paixão and Marlow, 2003). This trend has expanded the seaports' hinterland, creating a competition between neighboring seaports. That competition requires the seaports to focus not only on improvements within the seaport area but also on their inland access via functional inland intermodal terminals. Although inland intermodal terminals connected to seaports by rail have emerged around the world, there is no definitive consensus on which term to use; terms such as dry port are being advocated by some researchers (Rodrigue et al, 2010). The term dry port in this study refers to an inland intermodal terminal directly connected to seaport(s) by rail, where customers can leave/pick up their standardized units, as if directly at/from the seaport (Roso et al, 2009). Dry ports act as seaports' inland interface, offering services such as transshipment, value-added services such as storage, consolidation, depot, track and trace, container maintenance, and customs clearance that are usually available at seaports (Roso et al, 2009). As such, the concept emphasizes a higher level of integration with seaports. Port related transport processes along the transport chain should be seamless and the idea behind the dry port concept is to facilitate smooth transport flow (Roso and Rosa, 2012). In other words, the flow should not stop in the nodes; all node activities should be part of a seamless transport flow.

According to Roso (2013), dry port implementation brings competitive advantage to the seaport since it might expand the seaport's hinterland by improving the seaport's access to areas outside its traditional hinterland. Dry port implementation is not the only factor in relieving seaport congestion (Henttu and Hilmola, 2011) or improving seaport inland access (Hanaoka and Regmi, 2011); however, it is a significant component when it comes to improving seaport productivity. Dry port implementation should decrease $\mathrm{CO}_{2}$ emissions since rail service maximizes tonnage moved per gallon of fuel for shippers, helping them save costs and lower their environmental impact (Henttu and Hilmola, 2011; Roso, 2013), congestion at seaport terminals and seaport city roads should be avoided, and the risk of road accidents reduced (Roso et al, 2009). Apart from the general benefits of the shift from road to rail for the environment, inland ports offer seaports the possibility to increase their throughput without physical expansion at the seaport site (Roso et al, 2009). Furthermore, market-driven Outside-In development of inland intermodal terminals that generates higher level of integration with the seaports (Wilmsmeier et al, 2011) has been seen as very successful and very likely contributes to the viability of rail at short distances (Roso, 2013). The concept of the dry port has gained a lot of attention from researchers around the world who have studied the phenomenon from different perspectives. Many have identified success factors for dry ports for their specific cases. Black et al's (2013) study on dry port implementation in Asia summarizes the factors that influence dry ports' implementation and operations and, consequently, their success. However, as a part of intermodal transport solutions the dry port concept has issues with multiple transshipments that might increase costs, reliability and speed (Wiegmans et al, 2007).

\section{PORT ATTRIBUTES}

To inform our understanding of seaports, dry port activities and their level of implementation, data were collected from five U.S. East Coast Ports: Miami, Everglades, Jacksonville, Savannah and Charleston. These seaports have been chosen geographically, i.e. all five are situated very close to each other on the East Coast and all handle containers, approximately 1 million TEU or more in 2017. Face-to-face semi-structured interviews with seaport managers were conducted since this type of interview allows the interviewees to introduce new issues and the interviewer to follow up on topics more fully (Stuart et al, 2002). The interviewees were given a list of topics and discussion questions in advance. Triangulation with multiple means of data collection was used to ensure validity (Stuart et al. 2002). In addition to faceto-face interviews and site visits at seaports' terminals, secondary data were obtained from companies' websites, internal company reports, newspaper articles and presentations. Some additional e-mail correspondence was also conducted to clarify and fill the gaps in the data, as well as to validate the findings from the interviews.

\subsection{Port of Miami}

The Port of Miami is the US container port closest to the Panama Canal. In the year 2017 it handled 1,024,335 TEU, with imports mostly from Latin America and the Caribbean (Port 
to an all road drayage to the port of Savannah for their markets in southwest Georgia, southern Alabama, and western Florida. The success of CIP encouraged another project. The Appalachian Regional Port is a joint effort of the State of Georgia, Murray County, CSX and the Georgia Ports Authority. This inland port should provide a powerful new gateway to the Port of Savannah; it is estimated to take 50,000 trucks off Georgia highways, improve container availability and reduce transportation costs for port customers in Georgia, Alabama, Tennessee and Kentucky (GPA, 2018).

\subsection{Port of Charleston}

Publicly owned and operated, the Port of Charleston, South Carolina, handled a record-setting 2.14 million TEUs in 2017 on its two container cargo terminals (SCP, 2018). The Wando Welch Terminal (WWT) has received worldwide recognition for its innovative design. At present, it is the Port's largest terminal in terms of volume and physical size and frequently accommodates Post-Panamax and Suez-class container vessels. The North Charleston Terminal (NCT) is a modern container handling facility, complete with post-Panamax container cranes, an on-terminal container freight station, and an on-terminal rail yard. In addition to Wando and North Charleston, the Port is constructing a third container terminal (the Hugh K. Leatherman, Senior Terminal) to open in 2021. Columbus Street Terminal (CST) is Charleston's premier combination breakbulk and container terminal. The Port operates a cruise terminal, the Union Pier Terminal, and has an additional bulk/breakbulk terminal, Veteran's Terminal. The Port offers near-dock rail access, coordinates the drayage of containers between its terminals and the two local class-one railroads through a program called RapidRail. Nearly $25 \%$ of the total volumes are moved by rail and the port has daily express intermodal rail services through the CSX and Norfolk Southern systems.

Inland Port Greer (IPG) opened in October 2013, extending the Port of Charleston's inland access by 212 miles to Greer, S.C (WCN, 2013). IPG is owned by the South Carolina Ports Authority (SCPA) and double-stack rail service is provided exclusively by Norfolk Southern, providing shippers with access to more than 95 million consumers within a one-day drive. It acts like a freetrade zone and handles approx. 270,000 TEU. SCPA bought the land in Greer in the 1980s and started to lease the facility to BMW in early 1990s, which established a warehouse there. Since then, the port has the exclusive right to handle their containers. Other customers like Adidas and Michelin also use the facility, however, all customs clearance and inspections are done at the seaport. The inland port has an additional benefit since it gives regional shippers access to empty containers, allowing them to send trucks to Greer to pick up the containers they need to move their goods. The success of this inland port encouraged the port to build a second inland intermodal facility at Dillon, however, there was also demand for the enhanced efficiency of international container movements between the Port of Charleston and the growing markets in South and North Carolina (WCN, 2016b)." Inland Port Dillon will open in April 2018.

\section{DIFFUSION OF INNOVATION FRAMEWORK AND OBSERVATIONS}

The innovation to be studied is the dry port concept with its three critical components operating as one innovation, i.e., (1) on-dock rail, (2) reliable inland connection and (3) a functional intermodal inland facility, operating in coordination with one another, creating the dry port innovation.

With a growing demand for containerized freight transportation, efficient seaport inland access via dry ports is increasingly a necessity. If the attributes of successful innovations are understood, with respect to their influence specifically on dry ports, they can be managed to contribute to the successful implementation of dry ports. The novelty of the research lies in its approach of using the diffusion of innovation attributes, that have been historically proven to impact the adoption rates of innovations, to provide insight into the adoption of the dry port concept. To interpret the information gathered, this paper takes the diffusion of innovation approach to understanding the key influences on the adoption of dry port processes, particularly the processes involved in establishing trifecta of on-dock rail, reliable rail connection and a functional inland intermodal facility. The diffusion of innovation approach has already been successfully used in the supply chain context (Russell and Hoag, 2004) and provides a useful lens for assessing the innovation of the dry port concept. The elements of the diffusion of innovation model used to assess the dry port adoption issue are: (1) relative advantage, (2) trialability, (3) observability, (4) communication channels, (5) homophilious groups, (6) pace of innovation/ reinvention, (7) norm, roles and social networks, (8) opinion leaders, (9) compatibility, and (10) infrastructure. Below is a general description of each element, followed by an explanation of how the element informs our understanding of the adoption of dry ports.

The positive or negative impacts of the factors on the adoption of the inland port innovation are considered, based on literature and interviews, from the perspective of the stakeholders involved in the implementation of this innovation.

\subsection{Relative Advantage}

Relative advantage is the degree to which an innovation is perceived as better than the idea it supersedes. The degree of relative advantage may be measured in economic terms, but social-prestige factors, convenience, and satisfaction are 
objective evaluations are not entirely irrelevant, especially to the very first individuals who adopt. Instead, most people mainly depend on the subjective evaluation of an innovation conveyed to them by other individuals like themselves, who have previously adopted the innovation. This dependence on the experience of near peers suggests that the heart of the diffusion process consists of the modelling and imitation of network partners who have previously adopted (Rogers, 2003).

Communication channels are a missed opportunity for dry ports. In the current state of the port industry and particularly the dry port industry, there is limited communication about the three components among stakeholders. The lack of information transfer and collaborative decision-making contribute to the lack of diffusion of the dry port innovation. The port, the reliable rail connection and the functional inland facility all typically have separate information systems, separate means of sharing information with their suppliers and customers, and separate approaches to informing the media of their activities and performance. Without communication, it is difficult for others in the industry to understand the new innovation of the trifecta of the dry port concept.

\subsection{Homophilious Groups}

Homophilious Groups refers to homophily, i.e. the degree to which pairs of interacting individuals have certain attributes in common, such as beliefs, education, social status, and the like. In a free-choice situation, when an individual can interact with any one of a number of other individuals, there is a strong tendency for him to select someone who is most like him- or herself (Rogers, 2003).

Because the stakeholders involved in on-dock rail and reliable inland connections are a small network and geographically dispersed, the homophily or interaction with individuals with similar attributes is limited. There tends to be a larger network of stakeholders running functional inland facilities. However, as with several other influencers of innovation diffusion, the network of stakeholders who deal with all three components of the dry port concept is limited.

\subsection{Pace of Innovation/Reinvention}

The time dimension is relevant for diffusion: (1) in the innovation-decision process where an individual goes from first knowledge of an innovation to its adoption or rejection, (2) in the innovativeness of an individual or other unit of adoption compared with other system members, and (3) in an innovation's rate of adoption in a system, usually measured as the number of system members who adopt the innovation in a given time period (Rogers, 2003).

The pace of innovation in the trifecta of dry port components is hindered by the immense capital investment, required surface infrastructure improvements and the various agreements between stakeholders required for implementation. Probably the most difficult of these are the agreements between stakeholders, since different stakeholders have different business agendas. For example, the on-dock rail system stakeholders are looking to improve on-dock efficiency and throughput, but are not necessarily interested in the efficiency of the inland rail connection or the inland facility. Without incentive to ensure efficiency beyond the dock, stakeholders in the ondock rail system can knowingly or unknowingly slow the pace of innovation due to the lack of coordination with the other dry port components.

\subsection{Norms, Roles \& Social Networks}

A social system is defined as a set of interrelated units that are engaged in joint problem-solving to accomplish a common goal. Each unit in a social system is distinguishable from other units. All members cooperate at least to the extent of seeking to solve a common problem in order to reach a mutual goal. The sharing of a common objective binds the system together (Rogers, 2003).

Cooperation within the social system and the recognition of the common goal are imperative for the success of the dry port concept. Historically, each component operates in its own silo, passing off freight from one to another. However, the dry port concept requires that these components of on-dock rail, reliable inland connection and functional inland facility view themselves as one flow-through system, coordinating the many logistics activities, including scheduling, routing, security, loading, unloading and many other logistics activities.

\subsection{Opinion Leaders}

Opinion leadership is the degree to which an individual is able to influence other individuals' attitudes or overt behaviour informally in a desired way with relative frequency. It is a type of informal leadership, rather than a function of the individual's formal position or status in the system. Opinion leadership is earned and maintained by an individual's technical competence, social accessibility, and conformity to the system's norms (Rogers, 2003).

As the dry port concept gains momentum, opinion leaders, like those identified in the U.S. East Coast ports studies, will continue to emerge. As leaders gain traction and spread their influence in the industry, adoption is likely to be positively influenced. Of the three key components of dry ports, opinion leaders wield the most influence in the functional inland facility component, primarily because this is a mature industry. Since ondock rail and reliable inland connection are much more recent concepts, it will take time for opinion leaders to emerge. 


\subsection{Compatibility}

Compatibility is the degree to which an innovation is perceived as being consistent with the existing values, past experiences, and needs of potential adopters. An idea that is not compatible with the prevalent values and norms of a social system will not be adopted as rapidly as an innovation that is. The adoption of an incompatible innovation often requires the prior adoption of a new value system (Rogers 2003).

An innovation that is compatible with the existing values or needs of the systems should be rapidly adopted. Since two of the studied ports experience good compatibility of the dry port concept, future inland development plans are expected to be realized faster.

\subsection{Infrastructure}

Innovation adoption often depends on the presence or absence of some sort of infrastructure. Infrastructures can be hard, such as buildings, or soft like information systems. They enable spatial and temporal innovation diffusion (Rogers 2003).

Port of Jacksonville welcomed a 10100 TEU vessel, the largest containership to ever visit a Florida port, at the TraPac Container Terminal at Dames Point in the summer of 2017. The vessel transited the Suez Canal from Asia before reaching the U.S. East Coast, but not at full capacity due to the 40-foot depth of the channel at port entrance.

Three of the five studied ports have the status of "landlord ports", which was the main reason behind, e.g. Mitsui O.S.K Lines' investment in the Port of Jacksonville's TraPac Dames Point facility - the largest privately owned and operated terminal on the East Coast (TGC, 2017). Landlord ports are able to turn to local, state and/or federal government to deepen channels to make way for increasingly larger shipping vessels calling at ports, which is a huge advantage over operating ports. However, the successes of operating ports like Savannah and Charleston, are largely the result of embracing a vertically integrated structure - from maritime into inland distribution services, which might result in port regionalization as explained by Notteboom (2006). Furthermore, the model of directional development of intermodal inland ports/dry ports is closely related to the port-operation model, with the Outside-in model more often encountered in operating than landlord ports (Roso, 2013).

The main success factor, given the multiplicity of the agents involved, is to discuss operational agreements within a marketdriven development framework in advance. The preconditions are the coordination among various government agencies and the willingness of actors of the transport system to cooperate. And, there must be a railway connecting the seaport with the hinterland to allow container transfer from road to rail.

\section{ANALYSIS AND DISCUSSION}

Functional inland access to seaports is an important decision-making factor of seaport development strategies. It is also a significant factor that affects shipping companies' port choice. A seaport's natural or immediate hinterland is no longer defined by geographical distance alone, but by competition with other seaports as well, i.e. by the quality of the service at seaport terminals, as well as at their inland facilities (Roso, 2013). In other words, for many seaports, the battle for the sea is won inland via dry ports. The main features of the studied seaports are summarized in Table 1 which shows that operating ports handle two to four times more volume than landlord ports in any given year. We also observed that there are three components of the innovation trifecta present in the operating port business model. While the landlord ports show some elements of the key components of the dry port innovation, we came to the conclusion that landlord ports are not motivated by the same business goals as operating ports. This could be why landlord ports are slower at developing the infrastructure required for successful dry ports and why landlord ports experience the resultant low container volumes. Operating ports are driven by goals like growth and profit, which compel them to develop infrastructure that will provide ample capacity for increasing container volumes. Landlord ports, on the other hand, are driven by land usage; they appear to lack a common goal with all involved terminal operators, leaving the business goals of growth and profit to be achieved by the individual terminal operators.

In our assessment, dry port innovation is diffusing faster in the operating ports because both the seaport and the dry port are focused on the same goal. In the case of dry ports, there appears to be a high perceived relative advantage with respect to on-dock rail and a reliable rail connection.

The challenge of perceiving and ultimately adopting and utilizing the dry port concept is what makes the diffusion of innovation a useful assessment method. The diffusion of innovation helps us to theoretically understand what drives the adoption of new ideas, processes and products across many industries. Identifying areas that are working well and areas that need to be improved to achieve adoption and reap the benefits of innovations would be useful. The coordination trifecta requirement is what makes influencing the adoption of the dry port concept so difficult, while simultaneously making it a new and innovative approach to managing the growing volumes at seaports. The growth and changing needs of customers can not be successfully handled using old thinking and old processes. The problem must be seen in a new light, and solved accordingly.

In accordance with our first research question, the attributes of innovation diffusion having an impact on dry ports are illustrated in Figure 5.1 and fall into three categories: 
Table 1.

Summary of the studied seaports' attributes.

\begin{tabular}{llllll} 
Attributes & Miami & Everglades & Jacksonville & Savannah & Charleston \\
\hline Landlord/operating & Landlord & Landlord & Landlord & Operating & Operating \\
\hline On-dock rail & Yes & Near-dock & Yes* & Yes & Near-dock \\
\hline Reliable rail connection & Yes & Yes & No & Yes & Yes \\
\hline Functional inland facility & No & No & No & Yes & Yes \\
\hline Volumes handled & $\approx 1 \mathrm{mil}$ & $\approx 1 \mathrm{mil}$ & $\approx 1 \mathrm{mil}$ & 4 mil & *available but not in use
\end{tabular}

stakeholder perceptions, information transfer and challenge to secure facilities. Figure 5.1 shows a theoretical model of the innovation diffusion assessment of the dry port concept. Given the coordination required across infrastructure and organizations to achieve the full dry port concept, individual stakeholders need a mechanism for understanding relative advantage, and experiencing trialability and observability. The information transfer attributes focus on the timing, organization, quality and actors involved in the non-linear communication that must occur to support dry ports. These information transfer attributes include communication channels; norms, roles and social networks; homophilius groups and opinion leaders. The third group provides facilities and includes infrastructure and the pace of innovation/reinvention as it relates to establishing sustainable inland access at seaports, including three crucial components of the dry port concept: (1) on-dock rail, (2) reliable inland connection and (3) a functional inland facility. Each of these components has an eclectic group of stakeholders, many of whom are unknown to one another. The challenge is to create understanding between and motivate all stakeholders, regardless of their position in the inland access system, to realize the relative advantage of the full system i.e. the dry port concept.

As for our second research question, one of the key findings is that communication channels present a challenge across all stakeholders required for the successful adoption and utilization of dry ports. Another key finding is that on-dock rail is a challenge in all information transfer areas: communication channels; norms, roles and social networks; homophilius groups and opinion leaders. According to Wiegmans et al (2007) the costs of innovations related to transshipments in the rail sector are perceived as high, which might be one of the barriers to the successful adoption of the dry port concept since the rail, and inevitable transshipments, are its key components and as such influence relative advantage which is usually measured in economic terms.
These are impactful findings because they allow us to identify areas of focus to facilitate adoption, based on the time tested diffusion of the innovation lens.

Information transfer is another category of adoption attributes that has an impact on the adoption of the dry port concept. In this category, communication channels are a dominant attribute influencing adoption because there are numerous and varied stakeholders across the on-dock rail, inland rail connection and inland facility.

The challenge of ensuring facilities is the third category in our theoretical model shown in Figure 1. This is currently not a significant barrier.

\section{Stakeholder Perceptions}

- Relative Advantage

- Observability

- Trialability

\section{Information Transfer}

- Communication Channels

- Norms, Roles \& Social Networks

- Homophilious Groups

- Opinion Leaders

Challenge to Secure Facilities

- Infrastructure

- Pace of Innovation/ Reinvention

Figure 1.

Theoretical Model of Diffusion of Innovation for the Dry Ports Concept. 


\section{CONCLUSIONS}

This research contributes to the knowledge about dry ports by demonstrating that the successful implementation of the dry port concept depends on the coordinated adoption of three key components: (1) on-dock rail, (2) reliable inland rail connection, and (2) functional inland facility. It provides a fresh perspective and compels researchers to look for a new lens through which to view this trifecta of components that make-up the dry port concept. Our assessment, using the time tested diffusion of innovation approach, reveals that one of the key challenge areas in the diffusion of the dry port concept is information transfer among stakeholders. This is understandable and can be managed once understood. For example, understanding that there are no well developed and utilized communication channels, and that this attribute is key to success, can motivate disparate stakeholder groups to develop and use effective communication channels. These communication channels can complement the formation of homophilious groups where similar beliefs and education can be a cohesive factor helping achieve coordinated operations and successful implementation of the dry port concept.

Further research insights were gained in the area of stakeholder perceptions, revealing that the relative advantage of the dry port concept is not clear to key stakeholders, thus possibly inhibiting adoption.

Infrastructure, on the other hand, is clearly an area where the dry port concept demonstrates the attributes for successful implementation with advanced infrastructure available in the key component areas. A look through the innovation diffusion lens also makes clear that, infrastructure or not, if stakeholders cannot see the value, or relative advantage, and do not choose to communicate effectively across organizations, infrastructure will not be used to reap the benefits of the dry port concept. Furthermore, it was observed that the dry port innovation diffuses faster in operating ports because both the seaport and the dry port are focused on the same goal.

From the managerial perspective, this paper offers managers initiatives on which to focus to improve their success in the adoption of the dry port concept. In particular, it reveals that although technological communication tools required for the diffusion of the dry port concept abound, it will take business processes that foster an environment of defined communication channels, communication as a culture, and a network of industry professionals choosing to share information across stakeholders and industry boundaries to insure that the concept takes root and grows.

\section{ACKNOWLEDGEMENTS}

This research was funded by Chalmers Area of Advance Transport and Adlerbertska Research Scholarship.
Author Contributions: Conceptualization, V.R. and D. Russell; Methodology, V.R. and D. Russell; data collection and investigation V.R.; Analysis, all three authors; Writing, all three authors.

An earlier version of this paper based only on three cases has been presented at NOFOMA 2018 conference, and new shorter version of the paper based on five cases has been submitted and accepted for presentation at IMSC 2019 conference.

\section{REFERENCES}

Andersson, D. \& Roso, V., 2015. Developing Dry Ports Through the Use of ValueAdded Services. Lecture Notes in Logistics, pp.191-203. Available at: https://dx.doi.org/10.1007/978-3-319-21266-1_12.

Bask, A. et al., 2014. Development of seaport-dry port dyads: two cases from Northern Europe. Journal of Transport Geography, 39, pp.85-95. Available at: https://dx.doi.org/10.1016/j.jtrangeo.2014.06.014.

Beresford, A. et al., 2012. A study of dry port development in China. Maritime Economics \& Logistics, 14(1), pp.73-98. Available at:

https://dx.doi.org/10.1057/mel.2011.17.

Black, J., Kyu, T., Roso, V. \& Tara, K., 2013, Critical evaluation of Mandalay dry port, Proceedings 5th International Conference on Logistics and Transport 2013 (ICLT 2013), Sustainable Supply Chain Management in Asia Pacific, Doshisha University, Kyoto, pp. 107-114.

Black, J. et al., 2018. Issues in Dry Port Location and Implementation in Metropolitan Areas: The Case of Sydney, Australia. Transactions on Maritime Science, 7(1), pp.4150. Available at:

https://dx.doi.org/10.7225/toms.v07.n01.004.

Flämig, H. \& Hesse, M., 2011. Placing dryports. Port regionalization as a planning challenge - The case of Hamburg, Germany, and the Süderelbe. Research in Transportation Economics, 33(1), pp.42-50. Available at:

http://dx.doi.org/10.1016/j.retrec.2011.08.005.

Georgia Port Authority, 2016. Available at: http://www.gaports.com/Home.aspx

Georgia Port Authority, 2018. Available at: http://gaports.com/media/pressreleases/artmid/3569/articleid/189/savannah-teu-volume-reaches-42-million-infy 18

Hanaoka, S. \& Regmi, M.B., 2011. Promoting intermodal freight transport through the development of dry ports in Asia: An environmental perspective. IATSS Research, 35(1), pp.16-23. Available at:

https://dx.doi.org/10.1016/j.iatssr.2011.06.001.

Henttu, V. \& Hilmola, O.-P., 2011. Financial and environmental impacts of hypothetical Finnish dry port structure. Research in Transportation Economics, 33(1), pp.35-41. Available at:

http://dx.doi.org/10.1016/j.retrec.2011.08.004.

JaxPort, 2018. JAX Port Annual Report 2017. Available at: https://www.jaxport.com/ sites/default/files/images/JAXPORT\%202017\%20Annual\%20Report.pdf

Khaslavskaya, A. \& Roso, V., 2019. Outcome-Driven Supply Chain Perspectives on Dry Ports. Sustainability, 11(5), p.1492. Available at: http://dx.doi.org/10.3390/su11051492.

Korovyakovsky, E. \& Panova, Y., 2011. Dynamics of Russian dry ports. Research in Transportation Economics, 33(1), pp.25-34. Available at: http://dx.doi.org/10.1016/j.retrec.2011.08.008.

Miami Herald, 2018. Despite recent dredge, Port Miami still can't fit some large ships. New project in the works (July 2018). Available at: https://www.miamiherald. com/news/business/article214376334.html 
Monios, J., 2011. The role of inland terminal development in the hinterland access strategies of Spanish ports. Research in Transportation Economics, 33(1), pp.59-66. Available at:

http://dx.doi.org/10.1016/j.retrec.2011.08.007.

Ng, A.K. \& Tongzon, J.L., 2010. The transportation sector of India's economy: Dry ports as catalysts for regional development. Eurasian Geography and Economy, 51(5), pp. 669-682. Available at: https://doi.org/10.2747/1539-7216.51.5.669

Notteboom, T., 2006. Chapter 2 Strategic Challenges to Container Ports in a Changing Market Environment. Research in Transportation Economics, 17, pp.2952. Available at:

http://dx.doi.org/10.1016/s0739-8859(06)17002-x.

Paixão, A.C. \& Bernard Marlow, P., 2003. Fourth generation ports - a question of agility? International Journal of Physical Distribution \& Logistics Management, 33(4), pp.355-376. Available at:

http://dx.doi.org/10.1108/09600030310478810.

Port Everglades, 2015. Powerful Milestones Set New Records - Fiscal Year 2014 Commerce Report

Port Everglades, 2016. History. Available at: http://www.porteverglades.net/aboutus/history/

Port Everglades, 2018. Commerce Report Fiscal Year 2017.

Port Miami, 2016. Available at: http://www.miamidade.gov/portmiami/deepdredge.asp

Port Miami, 2017. Statistics at Glance - Port Miami 2017-2018 Port Report. Available at: http://www.miamidade.gov/portmiami/statistics.asp

Rodrigue, J.-P. et al., 2010. Functions and actors of inland ports: European and North American dynamics. Journal of Transport Geography, 18(4), pp.519-529. Available at:

http://dx.doi.org/10.1016/j.jtrangeo.2010.03.008

Rogers, M. E., 2003. Diffusion of Innovations. Free Press, NY.

Roso, V., 2007. Evaluation of the dry port concept from an environmental perspective: A note. Transportation Research Part D: Transport and Environment, 12(7), pp.523-527. Available at:

http://dx.doi.org/10.1016/j.trd.2007.07.001.
Roso, V., 2013. Sustainable intermodal transport via dry ports - importance of directional development. World Review of Intermodal Transportation Research, 4(2/3), p.140. Available at:

http://dx.doi.org/10.1504/writr.2013.058976.

Roso, V. \& Rosa, A., 2012. The dry ports in concept and practice, Song Dong-Wook and Panayides, P. M. (Eds) Maritime Logistics: A Complete Guide to Effective Shipping and Port Management, Kogan, London, pp. 179-194.

Roso, V., Woxenius, J. \& Lumsden, K., 2009. The dry port concept: connecting container seaports with the hinterland. Journal of Transport Geography, 17(5), pp.338-345. Available at:

http://dx.doi.org/10.1016/j.jtrangeo.2008.10.008.

Roso, V. et al., 2015. Seaport-inland port dyad dynamics: an investigation of service provisions and intermodal transportation linkages. World Review of Intermodal Transportation Research, 5(3), pp. 263-280. Available at: http://dx.doi.org/10.1504/writr.2015.069242.

South Carolina Ports, 2016. Available at: https://scpa.com/cargo

South Carolina Ports, 2018. South Carolina Ports Annual Report 2017. Available at: http://www.scspa.com/wp-content/uploads/scpa-annual-report-fy2017.pdf

Stuart, I. et al., 2002. Effective case research in operations management: a process perspective. Journal of Operations Management, 20(5), pp.419-433. Available at: http://dx.doi.org/10.1016/s0272-6963(02)00022-0.

The Grime Companies (TGC), 2017. Available at: http://www.grimescompanies. com/logistics-blog/106-landlord-port-model-cost-effective

Wiegmans, B.W., Hekkert, M. \& Langstraat, M., 2007. Can Innovations in Rail Freight Transhipment Be Successful? Transport Reviews, 27(1), pp.103-122. Available at: http://dx.doi.org/10.1080/01441640600765091.

Wilmsmeier, G., Monios, J. \& Lambert, B., 2011. The directional development of intermodal freight corridors in relation to inland terminals. Journal of Transport Geography, 19(6), pp.1379-1386. Available at: http://dx.doi.org/10.1016/j.jtrangeo.2011.07.010.

World Cargo News (WCN), 2013. Start made on Greer inland port, March 2013.

World Cargo News (WCN), 2016a. Big Ships, big problems, May 2016.

World Cargo News (WCN), 2016. Charleston to have second inland port, April 2016. 